\title{
低気圧空気中における針対平板ギャップの 負インパルスフラッシオーバ過程
}

$\begin{array}{llllll}\text { 正員 } & \text { 常 } & \text { 安 } & & \text { 湯 } & \text { (福网大) } \\ \text { 正員 } & \text { 嶋 } & \text { 崎 } & \text { 俊 } & \text { 行 } & \text { (福岡大) } \\ \text { 正員 赤 } & \text { 崎 } & \text { 正 則 (九州大) }\end{array}$

\section{1. まえがき}

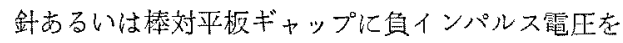
印加したときの破壊前駆現象については，既に幾つか の観測結果加報告されている(1) 一(5)。乙れらの報告に よると，その現象は正インパルス電圧印加時のそれよ りも更汇複雑である。このため，古る特定の条件机 ける現象の解明にも，その条件だけではなく，他の種

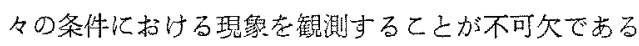
と考元られる。

ての上うな観点から，筆者ら牥気正，ギャップの長 さ，電極の形状，印加電圧の極性抢よび波形などの幅 広い条件に括ける現象索観測し，諸特性亡あわ女て考 察し，フラッシオーバ過程を系統的にはむくすること に努的さだ(6)(7)。

本諭文では，低気圧空気中の針対平板ギャップに， $1 \times 150 \mu \mathrm{s}$ の負インパルス電王を印加した時の放電状 況をイメージコンバータカメラを用いて篗測した結果 を示し，明らかにし得たフラッシオーバ過程をフラッ シオーバ諸特性と対志させて述べる。

\section{2. 実験方法亡装置}

直径が $0.5 \mathrm{~mm}$ で先端がほ澄半球状の白金線老高圧 側雪極, 直径が $50 \mathrm{~cm}$ の銅平円板を接地側電極とした

Flashover Processes of Needle to Plane Air Gaps in Low Pressure with Negative Impulses. By Itaru Tsuneyasu, Member, Toshiyuki Shimazaki, Member, (Eaculty of Engineering, Fukuoka Uniuersity) \& Masanori Akazaki, Member (Faculty of Engineering, Kyushu University).

常安 惕: 正昷, 福凧大学教授

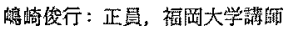

赤峭正則: 正圈, 九州大学教㹉
針対平板ギャップを，内径 $60 \mathrm{~cm}$ ，高さ $90 \mathrm{~cm}$ の䤣製 真空そう内にギャップ軸が踇直になるよう代置ぎ，ギ ヤップの長さを 1 ないし $10 \mathrm{~cm}$ の範围でよ变化した。て う内の空気は，いったん $0.5 \mathrm{mmHg}$ 程度まで排気し た後, 温度在 $20^{\circ} \mathrm{C}$ 程度, 湿度を $45 \%$ 程度に保った 室内空気を 30 ないし $500 \mathrm{mmHg}$ の範囲の所要の压 力になるまで注入した。針電極の紫外楾照射には水銀 灯を使用し石英レンズで集光した。

第 1 図に示した実験回路で， $1 \times 150 \mu \mathrm{s}$ の負インパ ルス電圧をギャップに盯加し，乙のときの $50 \%$ フラ ッシオーバ電壬およびフラッシオーバ時間を測定し， かつ放電状況を锥察した。50\%フラッシオーバ電圧 の決定は 25 回の界降法により, 電王印加の時間間鄵 は1 分り上とした。放霆状況の観測化はメージイン テンシファイヤを装着したイメージコンバータカメラ 老用い，同一条件での同樣な現彖们つても多数回日 を变えて繰返し行なった。フラッシオーバ直前までの

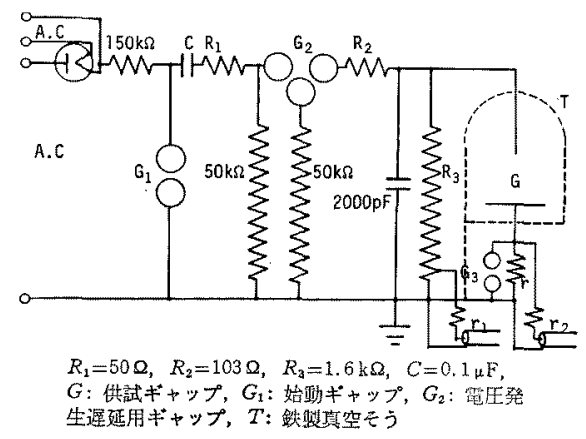

第 1 図実験回路

Fig. 1. Schematic diagram of experimental circuit. 
全体の状況䒚観测する際には比較的低速度の流し撮り

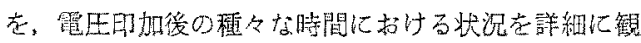

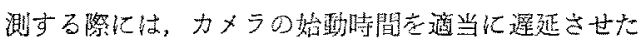

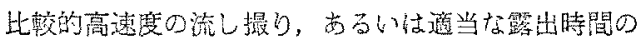
こま撮り行なった。またストリーマなどの淮跳速度 を測定する際仙は，イメージコンバータ管の陰極面に スリットを取付りて高速度り流し撯りをした。尖観測

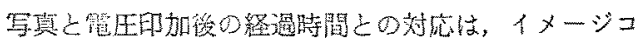
ンバータカメラのモニタパルスと盯加電正波形を 2 ビ ームシンタロスコープで効忘させる力法によった。

\section{3. 実験結果と考察}

〈3.1〉 $50 \%$ フラッシオーバ電压種々のギャッ プの長さ $d(\mathrm{~cm})$ 亿対する $50 \%$ フラッシオーバ電盾 $V_{s 0}(\mathrm{kV})$ と気在 $p(\mathrm{mmHg})$ との関原学 2 图化示す。 同図比見られるように， $d \geq 2.5 \mathrm{~cm}$ ではをれぞれに $V_{50}-p$ 特性が互いに相迲する二つの现力範团がある。

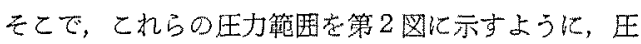
力の高い力加ら $A$ 領域枕よび $C$ 領域亡する。この上

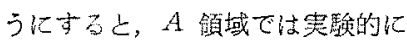

$$
V_{50}=3.0+18.6 p d / 760(\mathrm{kV})
$$

がは满成立し， $C$ 項域では

$$
V_{50}=(0.23+21.3 p / 760) d(\mathrm{kV})
$$

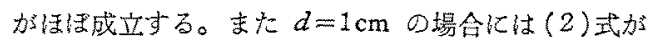
成立するので，乙の場合はその全域をC領域とした。

な就， $V_{50}$ 测定の際の禋準㴜差 $/ V_{50}$ の值仗 0.025 程度以下で馧子て小さい。

〈3.2〉 フラッシオーバ時間 第 3 図は $V_{50}$ を 25 回印加し，フラッシオーバしたときの電左印加後フラ

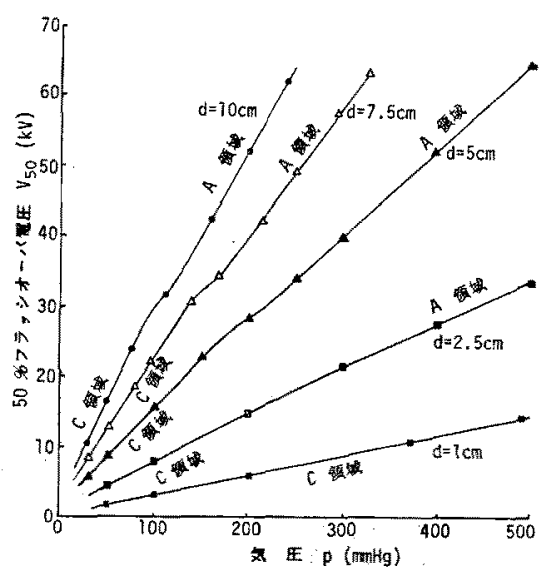

符 2 図 $50 \%$ フラッシオーバ電压 $V_{50}$ と気死 $p$

Fig. 2. $50 \%$ flashover voltage $V_{50}$ as a function of pressure.

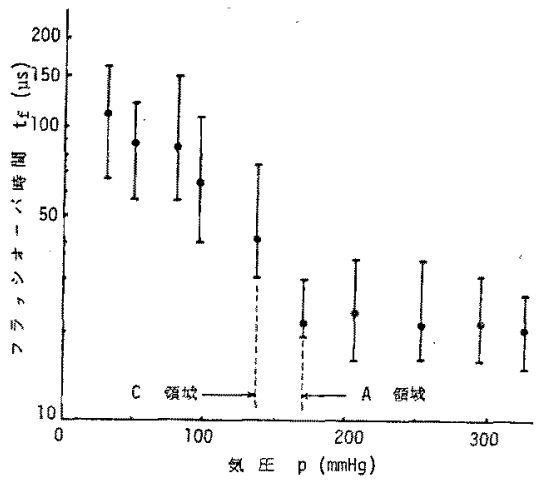

第 3 図 気压とフラッシオー八゙時間 $(d=7.5 \mathrm{~cm})$

Fig. 3. Relation between pressure and flashover time.

ッシオーバまでの時間，すおわらフラッシオ一ハ時間 ts の測定值それぞ約 12 個の平均値，最大値书上び 最小值と抜压之の関係を， $d$ が $7.5 \mathrm{~cm}$ の場合につい て示したものである。同图から明らかなように，C欲 域 $(d=7.5 \mathrm{~cm}$ の場合住 $p<140 \mathrm{mmHg})$ 《书付当 $t_{f}$ $の$ 值社 $A$ 領域 $(d=7.5 \mathrm{~cm}$ の之き $p \geq 170 \mathrm{mmHg}$ ) のそれよりもかなり大きい。他のdの值住対してるほ

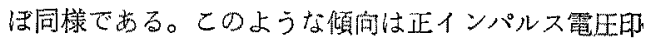
加時㹸も兒ら机る ${ }^{(8)(9)}$ 。

〈3.3〉 電圧一時間特性 $\quad d=7.5 \mathrm{~cm}$ の場合の電代 一封間特性を第 4 图儿示す。 $p$ 加 $30 \mathrm{mmHg}$ (C 領域) の場合は，同図(a)飞見られるように印加笔王 $V$ の 上昇と共に $t_{\text {～}}$ の値拉よびばらつきが減少し，通常上 くみられる倾向走示。但し，全般的にギャップの長

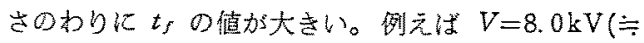
$\left.V_{50}\right)$ で $t_{f}$ は $100 \sim 140 \mu \mathrm{s}, V=8.6 \mathrm{kV}\left(\fallingdotseq 1.08 V_{50}\right)$ て 20〜27 «s 程度である。

$p$ が $220 \mathrm{mmHg}$ ( $A$ 領域) $の$ 場合は，第 4 図(b) 亿示すように $t_{f}$ は $V=43 \mathrm{kV}\left(\fallingdotseq V_{50}\right)$ のとき $29 \sim 36$.

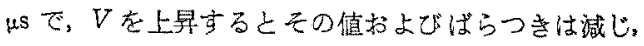
$V=47.7 \mathrm{kV}\left(\fallingdotseq 1.11 V_{50}\right)$ では 11 ない $14 \mu \mathrm{s}$ にな る。更に $V$ を上开させ $49 \mathrm{kV}\left(\fallingdotseq 1.14 V_{50}\right)$ にする

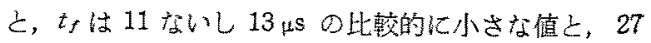

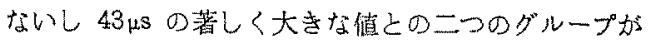
見ら机るようになる。V $50 \mathrm{kV}\left(\fallingdotseq 1.16 V_{50}\right)$ とす ると，衫は18ないし $27 \mu$ の大きな值のグループだ けになり，その後は $V$ の上昇之共に元の值战よびば らつき注減少する。すなわ方，この塨合は $1.14 V_{5}$ 程度の電死を印加したときに, 翼常に大きな值の $t_{f}$ が見られ，電圧一時間特性山互いに不速続な二本の曲 線で表わした方がより適切となる。同様な傾向は，A 


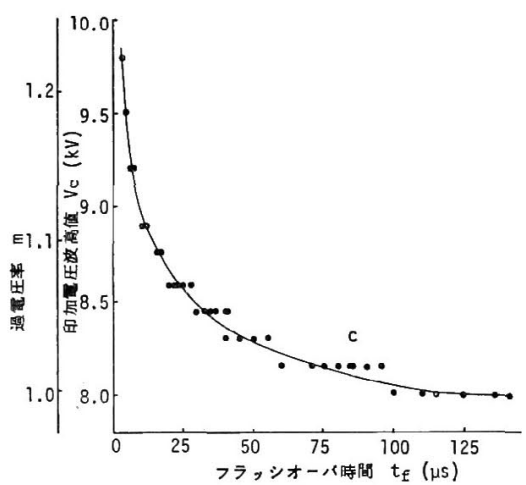

(a) $d=7.5 \mathrm{~cm}, p=30 \mathrm{mmHg}$ ( $C$ 領域)

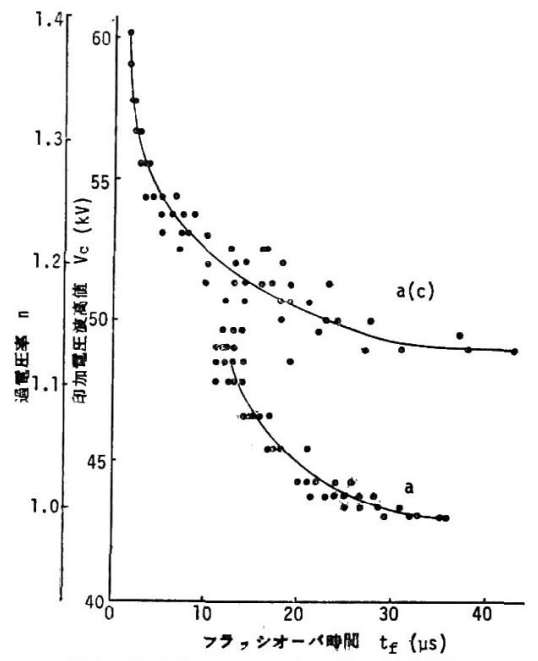

(b) $d=7.5 \mathrm{~cm}, p=220 \mathrm{mmHg}$ ( $A$ 領域)

第 4 図 電圧-時間特性

Fig. 4. $V-t$ characteristics.

領域の他の条件でも認められるが，気圧が高くなるほ ぞ, この傾向は弱まる。

$A$ 領域において，過電圧印加時に $t_{f}$ が異常に大き くなる現象は， $C$ 領域の実験式 (2)の計算値程度の電 圧を印加したときに起る。このような理由と後述の観 測結果から，第 4 図(b)では下方の曲線を $a$ ，上方の 曲線を $a(c)$ として示した。

〈3.4〉 フラッシオーバ過程 以上に述べた $V_{50}$ $p, d$ 特性, $t_{f}-p$ 特性就よび電圧一時間特性などから, $A$ 領域および $C$ 領域における $V_{50}$ 印加時のフラッシ オーバ過程が互いに相違すること，および $A$ 領域で は印加電圧の值によってもフラッシオーバ過程が相違 する場合があることが推測される。ここで，放電状況 を主としてイメージコンバータカメラを用いて観測し た。本節では得られた多数の観測結果加ら明らかにし
得たフラッシオーバ過程について述べる。Cおよび $A$ の各領域については，それぞれ代表的な場合の典型 的な筧測結果を例示し，フラッシオーバ過程を，その 概念図を提示して詳細に述へ，他の例については簡単 にふれる。

（1）C領域におけるフラッシオーバ過程

(a) $V_{50}$ 囵加時 $d=7.5 \mathrm{~cm}, p=30 \mathrm{mmHg}$ で, $V=8.1 \mathrm{kV}\left(\fallingdotseq V_{50}\right)$ の之きの観測結果を第 5 図に示す。 また第 6 図に，乙の場合のフラッシオーバ過程の概念

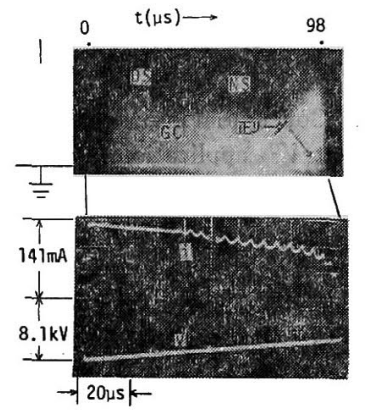

(a)

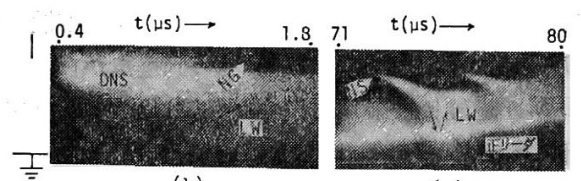

(b)

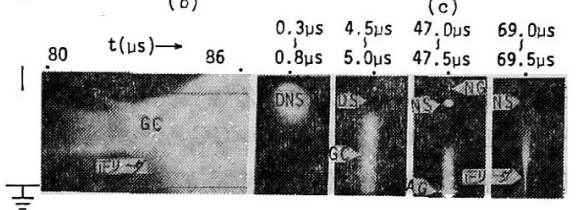

(d)

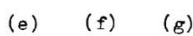

(h)

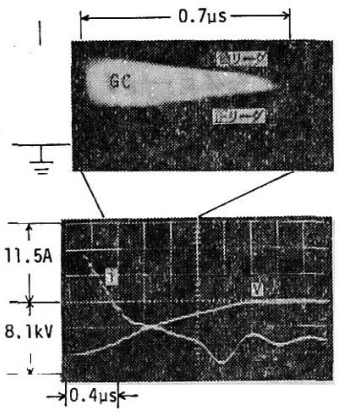

(1)

第 5 図 $C$ 領域に扔ける $V_{50}$ 印加洔の放電 状況とオシログラム $(d=7.5 \mathrm{~cm}$, $p=30 \mathrm{mmHg}, V=8.1 \mathrm{kV})$

Fig. 5. Photographs of discharge phenomena and oscillograms at $V_{50}$ application in the region $C$, 


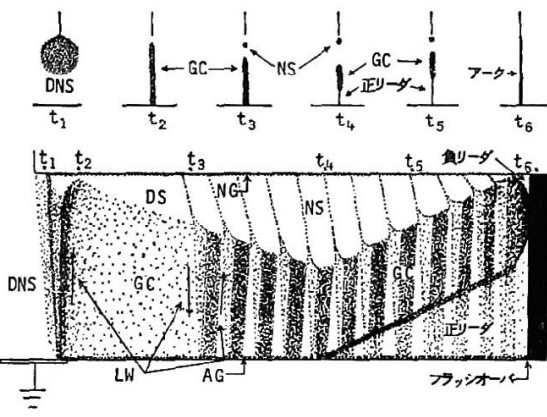

第 6 図 C 領域に抢ける $V_{50}$ 印加時の フラッシオーバ過程の概念図 (I)

Fig. 6. Conceptual figure of flashover process at $V_{50}$ application in the region $C(\mathrm{I})$.

図を下方に流し写真様式，その上方にてま撮り写真様 式で示した。この場合は電圧印加後,まず，針端加ら負 ストリーマDNS が進展する〔第 5 図( b ) 〕。乙の負ス トリーマは放射状に進展し, 拡散的な発光形状を示す 〔第5 四(e)〕ので，このようなストリーマを本論文 では「拡散負ストリーマ」と呼ぶことにする。拡散負ス トリーマが正極に到達すると, その到達点加ら, 発光 波LW が進展し〔第 5 図( b ) 〕，拡散負ストリーマの 内部，ほぼギャップ軸汇沿って円柱状のチャネルを形 成する[第 5 図(f)]。この円柱状のチャネルを正イン パルス電圧印加時に見られる同じようなチャネル ${ }^{(8)}$ そ 対応させるため，本諭文であグロー状チャネルと呼ぶ ことにする。グロー状チャネル GC が形成されると， その正極端には強く，汃長時間持続する発光域 $A G$ が現われる〔第 5 図(a), (c)，(g))。一方，針端に は拡散負ストリーマの発生後, 持続的な発光域 NG が 認めら机るようになる[第 5 図(b), (f), ( g ) )。その 後，正極を起点亡するグロー状チャネルの長さは次第 亿減少し，負極との間の暗部 DS が広がる〔第5 図 (a) J。電圧印加後 $40 \mu \mathrm{S}$ 程度経過した頃, 負極加ら発 光域 NS が発生し, その広がりと速度を增しながら, $1.5 \times 10^{6} \mathrm{~cm} / \mathrm{s}$ 程度の平均速度で進展してグロー状チャ ネルの上端に達する。こ机によって著しく高速度の発 光波がグロー状チャネル中を下方へ進展して正極に達 し, 反転して進展する。その後, 負極加ら発光域 NS 加問欠的に発生進展し〔第 5 図( a) , ( c ) ), 電流波形 にリップルを生じる(第 5 図( a))。この間にグロー状 チャネルの正極端が細く絞られ，乙の部分はグロー状 チャネルに沿い $2 \times 10^{5} \mathrm{~cm} / \mathrm{s}$ 程度の割合で次第にこの 長さを增す〔第 5 図(a), (c), (h))。これに伴いグ ロー状チャネルむ $2 \times 10^{5} \mathrm{~cm} / \mathrm{s}$ 程度の速度で負極方向
へ進展し, 結果として細く絞られたチャネルがグロー 状チャネルを負極方向へ押出すことになる。てのよう にしてグロー状チャネルが負極に達した直後にフラッ シオーバする第 5 図(d))。乙机らのととから，上述 の細く较られたチャネルは高い導電性を有し，かつそ れがフラッシオーバに果たす役割は正インパルス電圧 印加時の正リーダのそれ之 ${ }^{(8)(9)}$ 同様の屯の之考えられ る。そとで，ての場合む正リーダと呼ぶととにする。 正リーダとグロー状チャネルとの境界近傍，すなわち 正リーダ頭部の発光は特に強く〔第 5 図( $(a),(c)$, $(h)$ ， 乙の部分の電界は特に高いととが推測される。 正リーダがいったん進展を開始すると，その後連続的 に進展するのは, その頭部の高電界之持続的な放電電 流に上るむの之考えられる。正リーダ前面のグロー状 チャネルが負極に達すると, 電流は急增し, 負極加 負り一ダが進展を開始する。乙の負りーダが正リーダ と会すると電流は更に急増し, 端子電圧は極好て低い 值まで低下しフラッシォーバする。第 5 図(i)はての ときの状況を、レンズの絞りを極度に絞って撮影した 流し写真と，そのときの電圧電流オシログラムである。 同図では，フラッシオーバ直後のチャネルの発光が， グロー状チャネルのそれよりかなり弱い。しかし， フ ラッシオーバ時に更に大きな電力がギャップに注入さ れ得るように外部回路を変更すると, その発光は著し く強くなる(8)

次化 $d=7.5 \mathrm{~cm}, p=100 \mathrm{mmHg}$ (C 領域) で, $V=$ $23.0 \mathrm{kV}\left(\fallingdotseq V_{50}\right)$ の場合の流し写真之電圧, 電流オシロ グラムを第 7 図伅，フラッシオーバ過程の概念図を第 8 図示す。乙の場合は, 負極加らの間欠的な発光域 NS の進展覢ら机ない点を除くと, $d=7.5 \mathrm{~cm}, p=$

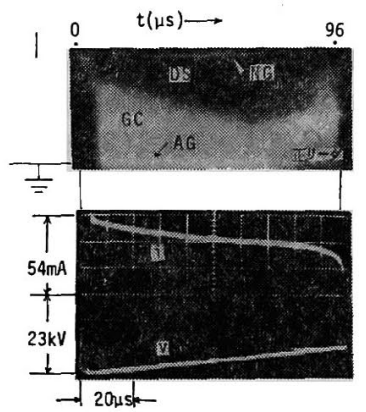

第 7 図 $C$ 領域における $V_{50}$ 田加時の放電 状況の流し写真とオシログラム $(d=7.5 \mathrm{~cm}$, $p=100 \mathrm{mmHg}, V=23.0 \mathrm{kV}$ )

Fig. 7. Streak photograph of discharge phenomena and oscillogram at $V_{50}$ application in the region $C$. 


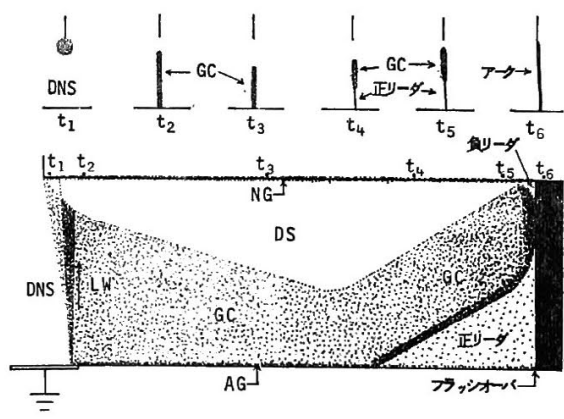

第 8 図 $C$ 領域における $V_{50}$ 印加時の フラッシオーバ過程の概念図 (II)

Fig. 8. Conceptual figure of flashover process at $V_{50}$ application in the region $C$ (II).

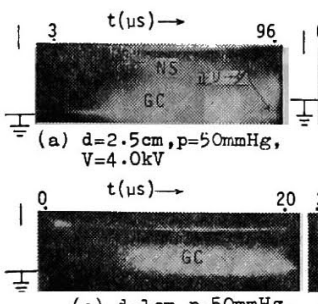

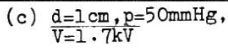

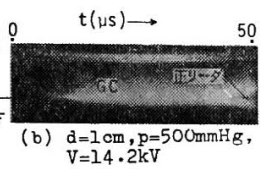

$t(\mu \mathrm{s}) \longrightarrow$

\section{ms:}

(d) $d=1 \mathrm{~cm}, p=50 \mathrm{mmHg}$, $\overline{\mathrm{V}}=1.7 \mathrm{kV}$
第 9 図 $C$ 領域における $V_{50}$ 印加時の 放電状況の流し写真

Fig. 9. Streak photographs of discharge phenomena at $V_{50}$ application in the region $C$.

$30 \mathrm{mmHg}$ の場合とほぼ同様な過程を経てフラッシオ 一バする。

第 9 図(a)および(b)はそれぞれ $d=2.5 \mathrm{~cm}$ で $p$ $=50 \mathrm{mmHg}$ および $d=1 \mathrm{~cm}$ で $p=500 \mathrm{mmHg}$, 同 図(c)およひ (d) はそれぞれ $d=1 \mathrm{~cm}$ で $p=50 \mathrm{~mm}$ $\mathrm{Hg}$ の場合の前半および後半の流し写真である。これ から, p が $50 \mathrm{mmHg}$ の場合のフラッシオーバ過程 は第6 図に示す過程とほぼ同様であり，500 $\mathrm{mmHg} の$ 場合は第 8 図に示す過程とほぼ同様であることがわか る。また負極加らの間欠的な発光域 NS の進展は，例 えば $d=7.5 \mathrm{~cm}$ の場合は約 $95 \mathrm{mmHg}$ 以下, $d=2.5$ $\mathrm{cm}$ の場合は約 $140 \mathrm{mmHg}$ 以下の低い気圧領域で見 られる。

次に $V_{50}$ を印加し，フラッシオーバしなかった場 合について述へる。このような例として,$d=7.5 \mathrm{~cm}$, $p=100 \mathrm{mmHg}$ のとき(C 領域) の放電状況の流し写 真と電圧, 電流オシログラムを第 10 図に示す。1× $150 \mu \mathrm{s}$ 波印加の場合〔第 10 図（ａ）〕は，グロー状チ ャネルはその形成後次第に長さを減じ，これと負極間

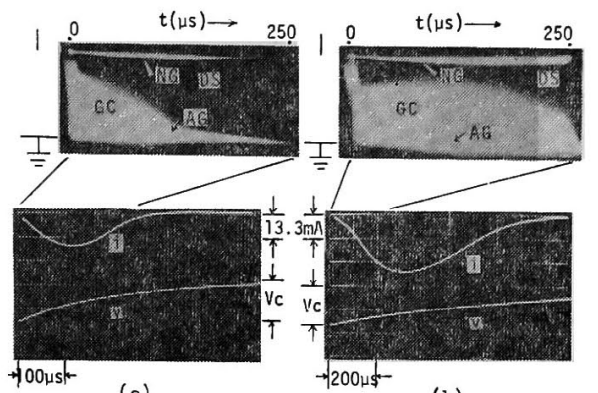

(a)

(b)

(a) $1 \times 150 \mu \mathrm{s}$ 波 $23 \mathrm{kV}\left(\fallingdotseq V_{50}\right)$ 印加

(b) $1 \times 600 \mu \mathrm{s}$ 波 $20 \mathrm{kV}\left(\fallingdotseq V_{50}\right)$ 印加

第 10 図 $C$ 領域に拈ける非フラッシオーバ 時の放電状況とオシログラム $(d=$ $7.5 \mathrm{~cm}, p=100 \mathrm{mmI}$ )

Fig. 10. Streak photographs of discharge phenomena and oscillograms when the air gap withstood at $V_{50}$ application.

の暗部 DS の長さが増す。しかし, 電流は次第に増加 し, 電圧印加後 $120 \mu \mathrm{s}$ 程度経過したころ, すなわち端 子電圧が約 $13.5 \mathrm{kV}$ に低下したころ, 電流はピーク值 〔第 10 図(a)では約 $20 \mathrm{~mA}$ 〕に達し, 発光域 $A G$ お よびNG の発光も強くなる。その後グロー状チャネル が消隇したころ, 端子電圧は $11 \mathrm{kV}$ 程度に低下してい るが，電流はなおピーク值の $85 \%$ 程度でかなり大き い。特に比較のために示した第 10 図(b) $(1 \times 600 \mu \mathrm{s}$ 波印加）の場合， $V_{50}$ は約 $20 \mathrm{kV}$ となり，グロー状チ ャネル形成当初の電流は著しく小さいが, その後電流 は次第に增加し, 電圧印加後 $300 \mu \mathrm{s}$ 程度経過し, 端 子電圧が $14 \mathrm{kV}$ 程度に低下したころピーク値（約 32 $\mathrm{mA}$ ）に達する。またグロー状チャネルはいったんは その長さを增すが, 電圧印加後, $400 \mu \mathrm{s}$ 程度で消隇す る。このように, グロー状チャネル形成後の時間の経 過上共に電流が增加し，端子電压がかなり低下したこ ろそのピーク值に達するととは, 持続的な電流の変化 が端子電圧の変化に即応できないことを示している。 これは電流と空間電荷分布とが相互に依存し，ギャッ プ中, 特に陰極領域の空間電荷の量と分布が持続的な 電流によって次第に変化し，てれがまた電流の変化を 生じ，次第にそのときの端子電圧に打ける定常状態に 近づこうとするからであると考えられる。従って，1 ンパルス電圧印加時のこのような放電は過渡的なグロ 一放電であり, 発光域 NG, 暗部 DS, グロー状チャ ネル拈よび発光域 $A G$ はそれぞれ負グロー,ファラデ ィー暗部，陽光柱抢よび陽極グロー上考えられる。

前述の上うに，電流が増加しているときに，陽極グ ロー部のチャネルが収縮して正リーダに移行し，これ 


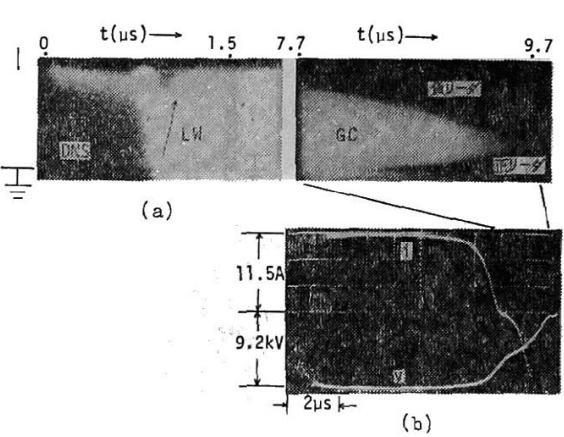

第 11 図 $C$ 領域における過電圧印加時の放

電状況とオシログラム $(d=7.5 \mathrm{~cm}, p=30$ $\mathrm{mmHg}, \quad V=9.2 \mathrm{kV}$ )

Fig. 11. Streak photographs of discharge phenomena and oscillogram at over-voltage application in the region $C$.
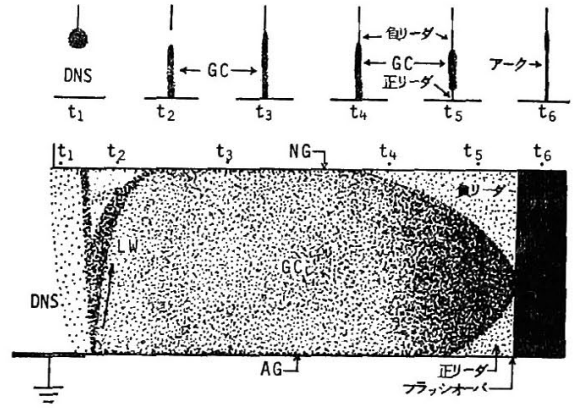

第 12 図 C 領域における過電压印加時の フラッシオーバ過程の概念図

Fig. 12. Conceptual figure of flashover process at over-voltage application in the region $C$.

が進展すると電流は更に急速に增加する。

（b） 過電圧印加時 $d=7.5 \mathrm{~cm}, p=30 \mathrm{mmHg}$ で $V=9.2 \mathrm{kV}\left(\fallingdotseq 1.15 V_{50}\right)$ のときの観测結果を第 11 図に，フラッシオーバ過程の概念図を第 12 図に示す。 この場合は，端子電圧が波高値に達するころまでにグ ロー状チャネルが形成されギャップを橋絡する。その 後, 電流が数アンペアになったてろ〔第 11 図(b)〕 グロー状チャネルの負極端がリーダに移行し，次いで 正極端もりーダに移行する。これらの負および正りー ダが進展して相会するとフラッシオーバする。

(2) $A$ 領域䎲拈けるフラッシオーバ過程

（a） $V_{50}$ 印加時 この場合の観測結果を第 13 図に,フラッシオーバ過程の概念図を第 14 図に示す。 まず拡散負ストリーマDNS〔第 13 図(f)〕によっ て形成された弱い発光域が正極に到達したとき，その 到達点から発生した発光波 LW がグロー状チャネル

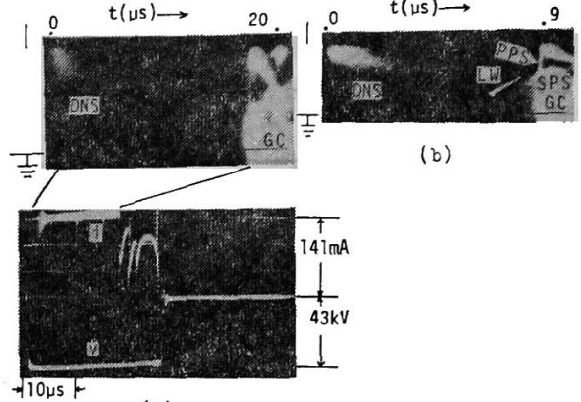

(a)

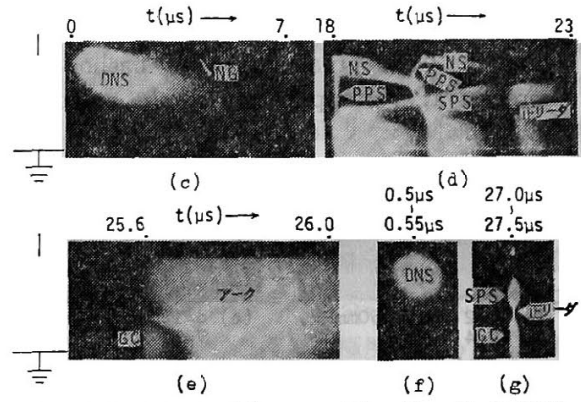

(a), (c ) $\sim$ (g) : $d=7.5 \mathrm{~cm}, p=220 \mathrm{mmHg}, V=43.0 \mathrm{kV}$

(b) : $d=2.5 \mathrm{~cm}, p=350 \mathrm{mmHg}, V=24.5 \mathrm{kV}$

第 13 図 $A$ 領域における $V_{50}$ 印加時の 放電状況とオシログラム

Fig. 13. Photographs of discharge phenomena and oscillogram at $V_{50}$ application in the region $A$.

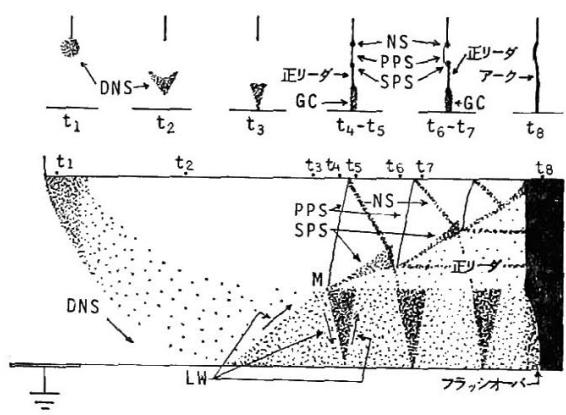

第 14 図 $A$ 領域における $V_{50}$ 印加時の フラッシオーバ過程の概念図

Fig. 14. Conceptual figure of flashover process at $V_{50}$ application in the region $A$.

を形成しながらある距離を進展すると，攵ロー状チャ ネルの頭部から一次正ストリーマが進展し，ほぼ同時 に，その起点から二次正ストリーマと正極向け発光波 が進展する〔第 13 図(b)〕。二次正ストリーマSPS は 一次正ストリーマPPS の進展経路に沿い, それよりも 著しい低速度で進展し，発光が持続的なチャネルを形 
成する。一方, 正極へ向かった発光波は正極で反転し て進展し,グロー状チャネルの発光を強的るまた一次 正ストリーマは $4 \times 10^{7} \mathrm{~cm} / \mathrm{s}$ 程度の速度で進展して目 極に達し，負極から負ストリーマNSを進展させる〔第 13 困(d)J。この間に二次正ストリーマ基部が細く絞 られ正リーダに移行する〔第 13 図(d), (g))。その 後正リーダから一次正ストリーマが間欠的に発生進展 し，その都度二次正ストリーマと正極向け発光波が進 展して正リーダむその長さを增す。このような過程を 経て二次正ストリーマが負極に達すると, 電流が急増 し，その直後にフラッシオーバする。このとき，グロ 一状チャネルからアーク柱への移行には, チャネルの 他の部分よりあやや時間を要する(第 13 図(e)】。上 述のグロー状チャネル頭部からの一次正ストリーマ発 生以後の過程は，大気中正針対平板ギャップにおける フラッシオーバ過程と極めて良く似ている(8)(9)。

（b） 過電圧印加時 印加電圧を $V_{50}$ 加ら上昇 すると，拡散目ストリーマの正極到達時間が早くなり その到達点から進展する発光波の速度も速くなる。ま た,グロー状チャネルの長さが長くなり, フラッシオ 一バまでの正ストリーマの発生回数が少なくなる。こ のため $V$ が高いほよ゙ $t_{f}$ は小さくなる。Vが $(1)$ 式 程度になると，端子電圧が波高值に達するころ，負極 加ら強い発光波功発生し，拡散負ストリーマ内を進展 して拡散負ストリーマのほぼ全域の発光を強めること がある。第 15 図は，このような場合の観測写真であ る。このときは，グロー状チャネルは一次正ストリー マを発生することなく，負極近傍で進展を停止する 〔第 15 図(a)〕。乙れは前述の拡散負ストリーマの発 光を著しく強める発光波によって形成された電子群が 若干, 正極方向へドリフトしたころにグロー状チャネ ルが形成され, この頭部は電子密度の高い領域の負極 端で進展を停止する。この上き，その真極側には豊富 な正空間電荷が存在するため，グロー状チャネル頭部 の負極側電界が弱く，正ストリーマ発生の条件が満た (a)

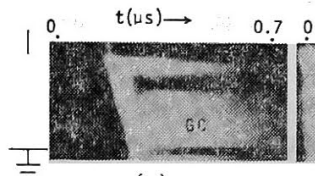

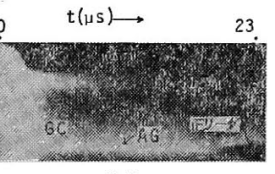

(b)
第 15 図 $A$ 領域に少ける過電圧印加時の 放電状況 $(d=7.5 \mathrm{~cm}, p=220$ $\mathrm{mmHg}, V=49.2 \mathrm{kV})$

Fig. 15. Streak photographs of discharge phenomena at over-voltage application in the region $A$.
されなくなるからであると考えられる。この場合は， グロー状チャネルの正極端がまずリーダに移行し, $V_{50}$ 印加時の $C$ 領域之ほぼ同様の過程〔第 15 図( b ) 〕を 経てフラッシオーバし， $t_{f}$ が㿽常に大きくなる。

印加電圧を更に高的ると，グロー状チャネルはギャ ップを橋絡し， C 領域で過電圧印加時の過程（第 12 図）と同様の過程を経てフラッシオーバする。

〈3.5〉負ストリーマとグロー状チャンネルおよび 一次正ストリーマ $A, C$ いず狆の領域に执いても, まず抎散負ストリーマが進展する。ギャップの端子電 圧が上昇している間は拡散負ストリーマ内部のほぼ全 域にわたって発光が持続し，その進展速度む比較的に 速い。しかし，端子電圧が波高值に達した後は，その 進展速度，発光の強さが低下し，発光域が正極方向一 移動するのに伴い，その負極側には，暗部 DS が広が る。これらのことから次のようなととが考えられる。 すなわち，拡散負ストリーマの発生進展により針端周 辺に正イオンが集積し，これと針端間の電界が高くな る。一方その外側, 負空間電荷が存在する領域との間 の電界は低下する。しかし，端子電圧の上昇が急であ る間はこの電界緩和効果が補償され, 負空間電荷存在 領域の電界は高く，この部分の励起扔よび電離係数も 比較的に大きく, 電子密度の高い負空間電荷領域が急 速に広がる。端子電圧が波高值に達した後は，負電荷 のドリフトに伴い，拡散目ストリーマの発光域が正極 方向へ移動すると共に，その負極側には低電界領域が 広かる。従って, DS の電子密度は拡散負ストリーマ 先端部のそれに比しかな低いと考えられる。

拡散負ストリーマが正極に接近すると共に，その前 縁部中央部が次第に突出して正極に達すると，その点 から発光波が進展して径の太いグロー状チャネルが形 成される。この発光波は比較的に電子密度の高い空間 を伝搬する局部的な高電界域であり，既に存在してい る電子がこの高電界域に集中し, 更に電子密度の高い グロー状チャネルが形成されるあのと考えられる。乙 の発光波は，その伝搬速度汃印加電圧の值によって大 幅に变化し（本実験では $8 \times 10^{5}$ ないし $3 \times 10^{7} \mathrm{~cm} / \mathrm{s}$ ) 程度), Loeb 氏ら ${ }^{(10)}$ による電離電圧波に対応する場 合もあり，電圧波に対応する場合むあると考えられる が，観测による両者の区別は困難である。この発光波 が拡散負ストリーマの発光域を伝搬し，DS に達する と, この部分の電子密度が低いため, グロー状チャネ ルの形成は止む。前述のように拡散負ストリーマ進展 中の DSの電界は比較的に低いと考えられるが，この とき負電荷群は放射状に広い範团に広がっている。し かしグロー状チャネルが形成されると, 正極を起点と 
する月柱状チャネルと針電極とが対向することにな り、グロ一状チャネル頭部近傍の電界が高くなり，電 子なだ机らストリーマへの枟换が可能になる場合む 起り得る。この場合はグロー状于ャネル頭部から一次 正ストリーマが進展し得る。

〈3.6〉 フラッシオーバ過程とフラッシオーバ特性 グロー状チャネルが形成さ机た後, 更にフラッシオ 一バするにはりーダが進展してギャップを橋絡する必 要がある。このリーダの進展開始に次の三つの場會が

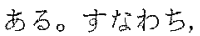

(1) グロー状チャ亦ルがほぼギャップを橋絡し，ま ずその負極端がリーダに移行する場合

(2) 正極を起点とするグロー状チャネルがギャップ 中間で進展を停止し，之の上端（負極側端）加ら一次 正ストリーマが進展し，乙れによる二次正ストリーマ の基部がリーダに移行する晹合

(3) ギャップ中間で進展を停止したグロー状チャネ ルの正極端肪りーダに移行する場合 などでる。

以上のうち，(1)拡散負ストリーマのはぽ全域にわ たって発光が持続している間, 従って端子電圧が波高 值に達する以前にグロー状于ャネルが形成されるよう な十分に高い電圧を印加した場合に起り，(2)はグロー 状チャネルが形成されたとき，之の頭部近傍の電界が 電子なだれから正ストリーマへの枟换を可能とする上 うな值と分布になるととが必要であり，また(3はグロ 一状チャネルの正極端，すなわち陽極グローの高電界 上過渡的なダロー放電による十分な電流密度が必要で あると考元ら机る。徉って，(2)上(3)加必要之する条件 は互いに相違する。結局, 実踭式 (1)は $1 \times 150 \mu \mathrm{s}$ 波 印加時に(2)の過程老経てフラッシオーバする場合の $V_{50}$ を与え，(2)式は(3)の過程を経てフラッシオーバ 卞る場合の $V_{50}$ を与元ている。

以上の理由から， $A$ 領域と $C$ 領域とては $V_{50}-p$ 特 性， $t_{f}-p$ 特性に明ら加な差異加生じる。また $A$ 領域 で過電王を印加した場合に，(3)の過程でフラッシオー バする場合があり，乙の場合は第 4 図(b)に見られる ような特異な電压一時間特性を示すことになる。

\section{4. むすび}

本論文で述べたところを要約すると，

(1) $V_{50}-p$ 特性が，互い相逢するギャップの長 さと圧力範图がある。実験式(1)㧍よび(2)が成立す る範囲をそれぞれ $A$ 領域拉よび $C$ 領域とした。

(2) $A$ 領域では， $V_{50}$ 印加時のフラッシオー八゙時 間加 $C$ 領域のそれよりもか子り小さく，電死一時間特 性が互いに不連続な 2 本の曲線で表わせる場合があ 万。

（3）搪散負ストリーマ，グロー状チャ齐ル，一次 正ストリーマの進展などについて考察を加えた。

（4）リーダの進展閒始に 3 種類の場合があり，乙 れらについて述べた。

（5）フラッシホーバ過程の詳細を述へ，てれらを フラッシオーバ諸特性上関連つけた。

以上，本研究ではギャップの長さが比較的に短い針 対平板ギャップに負インパルス電圧を印加したときの フラッシオーバ過程を明ら加にし，フラッシオーバ諸 特性と対広づけた。

しかしギャップの長さ，その他の条件が買なる 上，フラッシォーバ過程および特性は複雑に裂化する ととが予想され，特に長ギャップにおける現象はかな り様相を翼にするので, 今後, 更に種々の条件に招け る現象について研究を進兴予定である。

(昭和 51 年 3 月 31 日受付, 同 51 年 9 月 27 日再受付)

\section{文献}

(1) I.S. Stekol'nikov, et al. Soviet Phys,-Doklady 7, 712 (1963-2)

(2) I.S. Stekol'nikov, et al.: ibid. 8, 829 (1864-2)

(3) 原圆: 電中研款告 No.65061，1 (昭 40-10)

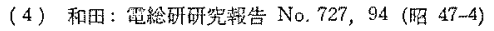

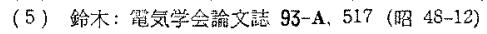

（6）常军·赤㱦：同上 93-A，487（昭 48-11)

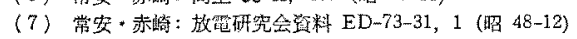

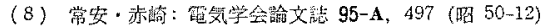

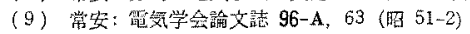

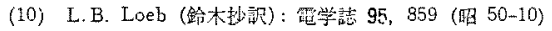

